\title{
Insulin-like growth factor 1 (IGF-1): a growth hormone
}

\author{
Z Laron
}

\begin{abstract}
Aim-To contribute to the debate about whether growth hormone (GH) and insulin-like growth factor 1 (IGF-1) act independently on the growth process. Methods-To describe growth in human and animal models of isolated IGF-1 deficiency (IGHD), such as in Laron syndrome (LS; primary IGF-1 deficiency and GH resistance) and IGF-1 gene or GH receptor gene knockout (KO) mice.

Results-Since the description of LS in 1966, 51 patients were followed, many since infancy. Newborns with LS are shorter $(42-47 \mathrm{~cm})$ than healthy babies (49-52 cm), suggesting that IGF-1 has some influence on intrauterine growth. Newborn mice with IGF-1 gene KO are $30 \%$ smaller. The postnatal growth rate of patients with LS is very slow, the distance from the lowest normal centile increasing progressively. If untreated, the final height is $100-136 \mathrm{~cm}$ for female and $109-138 \mathrm{~cm}$ for male patients. They have acromicia, organomicria including the brain, heart, gonads, genitalia, and retardation of skeletal maturation. The availability of biosynthetic IGF-1 since 1988 has enabled it to be administered to children with LS. It accelerated linear growth rates to $8-9 \mathrm{~cm}$ in the first year of treatment, compared with 10-12 cm/year during GH treatment of IGHD. The growth rate in following years was $5-6.5 \mathrm{~cm} /$ year.
\end{abstract}

Conclusion-IGF-1 is an important growth hormone, mediating the protein anabolic and linear growth promoting effect of pituitary GH. It has a GH

Accepted 24 April 2001

(CNS)

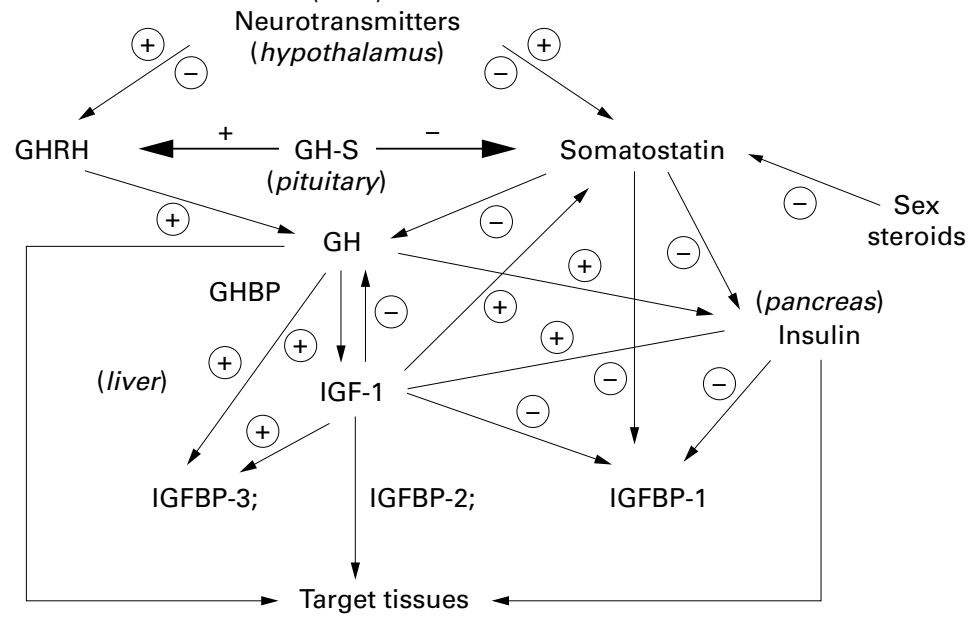

Figure 1 The cascade of the growth hormone axis. CNS, central nervous system; GH, growth hormone; GHBP, GH binding protein; $G H-S$, $G H$ secretagogues; IGF-1, insulin-like growth factor 1; IGFBPs, IGF binding proteins; +, stimulation;-, inhibition. independent growth stimulating effect, which with respect to cartilage cells is possibly optimised by the synergistic action with GH.

(f Clin Pathol: Mol Pathol 2001;54:311-316)

Keywords: insulin-like growth factor I; growth hormones; Laron syndrome; growth

In recent years, new technologies have enabled many advances in the so called growth hormone $(\mathrm{GH})$ axis (fig 1 ). Thus, it has been found that $\mathrm{GH}$ secretion from the anterior pituitary is regulated not only by $\mathrm{GH}$ releasing hormone (GHRH) and somatostatin (GH secretion inhibiting hormone), ${ }^{1}$ but also by other hypothalamic peptides called GH secretagogues, ${ }^{2}$ which seem to act in synergism with $\mathrm{GHRH}^{3}$ by inhibiting somatostatin. ${ }^{4}$ One of these has been cloned and named Ghrelin. ${ }^{5}$ The interplay between GHRH and somatostatin induces a pulsatile $\mathrm{GH}$ secretion, ${ }^{6}$ which is highest during puberty. $\mathrm{GH}$ induces the generation of insulin-like growth factor 1 (IGF-1, also called somatomedin 1) in the liver and regulates the paracrine production of IGF-1 in many other tissues. ${ }^{7}$

\section{IGF-1}

IGF-1 and IGF-2 were identified in 1957 by Salmon and Daughaday ${ }^{8}$ and designated "sulphation factor" by their ability to stimulate ${ }^{35}$-sulphate incorporation into rat cartilage. Froesch et al described the non-suppressible insulin-like activity (NSILA) of two soluble serum components (NSILA I and II). ${ }^{9}$ In 1972, the labels sulphation factor and NSILA were replaced by the term "somatomedin", denoting a substance under control and mediating the effects of $\mathrm{GH} .{ }^{10}$ In 1976, Rinderknecht and Humbel ${ }^{11}$ isolated two active substances from human serum, which owing to their structural resemblance to proinsulin were renamed "insulin-like growth factor 1 and 2" (IGF-1 and 2). IGF-1 is the mediator of the anabolic and mitogenic activity of $\mathrm{GH} .{ }^{12}$

\section{CHEMICAL STRUCTURE}

The IGFs are members of a family of insulin related peptides that include relaxin and several peptides isolated from lower invertebrates. ${ }^{13}$ IGF-1 is a small peptide consisting of 70 amino acids with a molecular weight of $7649 \mathrm{Da}^{14}$ Similar to insulin, IGF-1 has an A and $\mathrm{B}$ chain connected by disulphide bonds. The $\mathrm{C}$ peptide region has 12 amino acids. The structural similarity to insulin explains the ability of IGF-1 to bind (with low affinity) to the insulin receptor. 


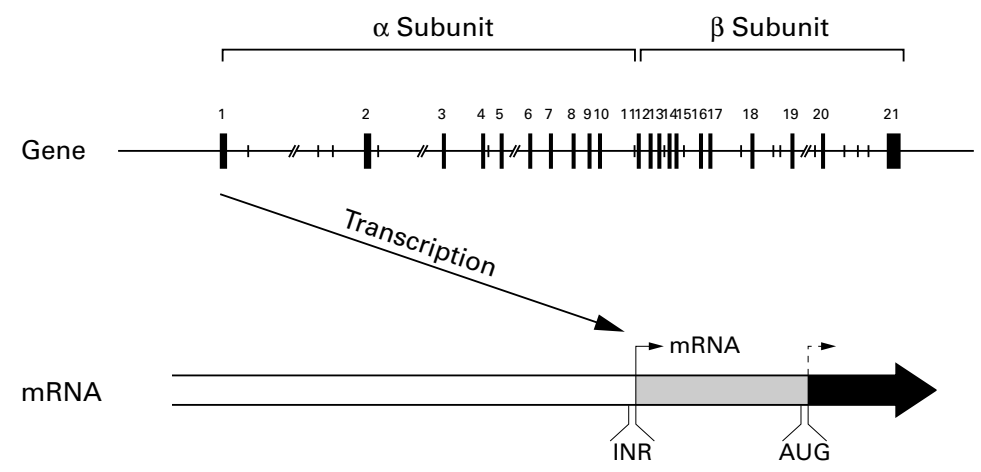

Figure 2 Type 1 insulin-like growth factor receptor gene and $m R N A$. Reproduced with permission from Werner. ${ }^{22}$ $\alpha$ subunits and transmembrane $\beta$ subunits. The $\alpha$ subunits have binding sites for IGF- 1 and are linked by disulphide bonds (fig 3 ). The $\beta$ subunit has a short extracellular domain, a transmembrane domain, and an intracellular domain. The intracellular part contains a tyrosine kinase domain, which constitutes the signal transduction mechanism. Similar to the insulin receptor, the IGF-1 receptor undergoes ligand induced autophosphorylation. ${ }^{25}$ The activated IGF-1 receptor is capable of phosphorylating other tyrosine containing substrates, such as insulin receptor substrate 1 (IRS-1), and continues a cascade of enzyme activations via phosphatidylinositol-3 kinase (PI3-kinase), Grb2 (growth factor receptor bound protein 2), Syp (a phophotyrosine phosphatase), Nck (an oncogenic protein), and Shc (src homology domain protein), which associated to Grb2, activates Raf, leading to a cascade of protein kinases including Raf, mitogen activated protein (MAP) kinase, $5 \mathrm{G}$ kinase, and others. ${ }^{26}$

\section{Physiology}

IGF-1 is secreted by many tissues and the secretory site seems to determine its actions. Most IGF-1 is secreted by the liver and is transported to other tissues, acting as an endocrine hormone. ${ }^{27}$ IGF-1 is also secreted by other tissues, ${ }^{28}$ including cartilagenous cells, and acts locally as a paracrine hormone (fig 4). ${ }^{29}$ It is also assumed that IGF- 1 can act in an autocrine manner as an oncogene. ${ }^{30}$ The role of IGF-1 in the metabolism of many tissues including growth has been reviewed recently. ${ }^{31} 32$

The following is an analysis of whether IGF-1, the anabolic effector hormone of pituitary GH, is the "real growth hormone".

The human IGF-1 receptor (type 1 receptor) is the product of a single copy gene spanning over $100 \mathrm{~kb}$ of genomic DNA at the end of the long arm of chromosome $15 \mathrm{q} 25-26 .{ }^{22}$ The gene contains 21 exons (fig 2) and its organisation resembles that of the structurally related insulin receptor (fig 3). ${ }^{23}$ The type 1 IGF receptor gene is expressed by almost all tissues and cell types during embryogenesis. ${ }^{24}$ In the liver, the organ with the highest IGF-1 ligand expression, IGF-1 receptor mRNA is almost undetectable, possibly because of the "downregulation" of the receptor by the local production of IGF-1. The type 1 IGF receptor is a heterotetramer composed of two extracellular spanning

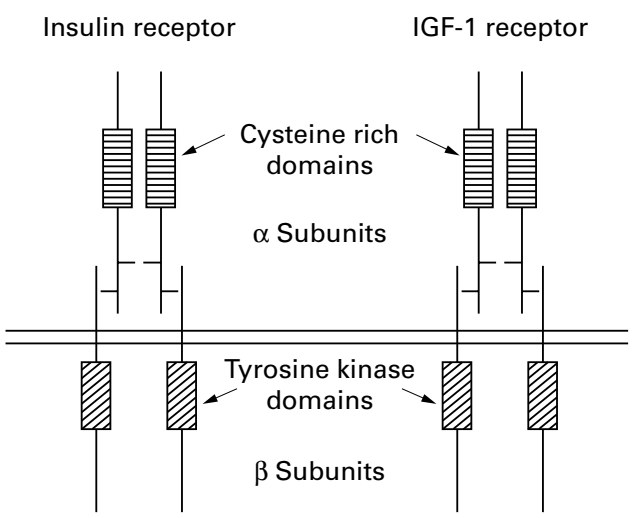

Figure 3 Resemblance between the insulin and insulin-like growth factor 1 (IGF-1) receptors.

\section{Is IGF-1 "a" or "the" growth hormone?}

The discussion on the role of IGF-1 in body growth will be based on growth in states of IGF-1 deficiency and the effects of exogenous IGF-1 administration. Experiments in nature (gene deletion or gene mutations) or experimental models in animals, such as gene knockouts, help us in this endeavour. In 1966 and 1968,334 we described a new type of dwarfism indistinguishable from genetic isolated $\mathrm{GH}$ deficiency (IGHD), but characterised by high serum $\mathrm{GH}$ values. Subsequent studies revealed that these patients cannot generate IGF- $1 .{ }^{35}$

This syndrome of $\mathrm{GH}$ resistance (insensitivity) was named by Elders et al as Laron dwarfism, ${ }^{36}$ a name subsequently changed to Laron syndrome (LS). ${ }^{37}$ Molecular studies revealed that the causes of $\mathrm{GH}$ resistance are deletions ${ }^{38}$ or mutations ${ }^{39}$ in the $\mathrm{GH}$ receptor gene, resulting in the failure to generate IGF-1 and a reduction in the synthesis of several other substances, including IGFBP-3. This unique model in humans has enabled the study of the differential effects of $\mathrm{GH}$ and IGF-1.

\section{Growth and development in congenital (primary) IGF-1 deficiency (LS)}

Our group has studied and followed 52 patients (many since birth) throughout childhood, puberty, and into adulthood. We found 


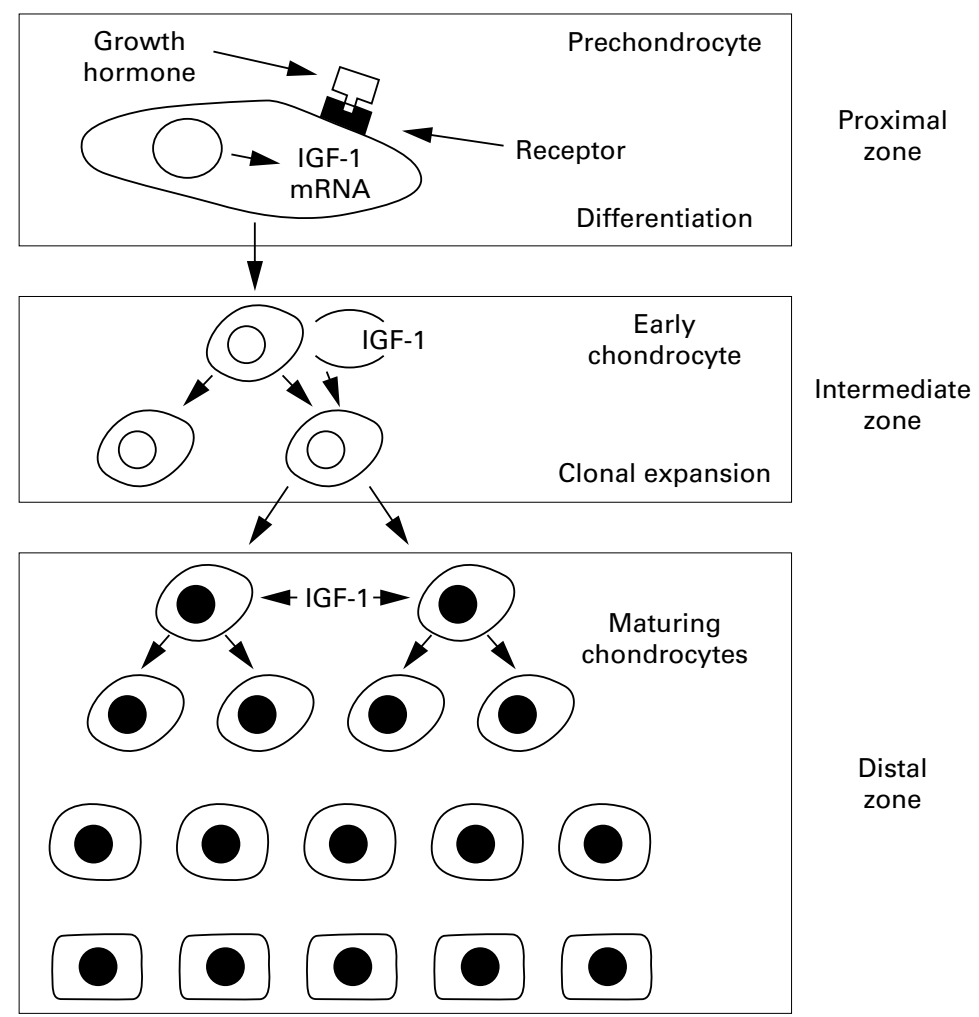

Figure 4 Paracrine insulin-like growth factor 1 (IGF-1) secretion and endocrine IGF-1 targets in the various zones of the epiphyseal cartilage growth zone.

that newborns with LS are slightly shorter at birth $(42-47 \mathrm{~cm})$ than healthy babies (49$52 \mathrm{~cm}$ ), suggesting that IGF-1 has some influence on intrauterine linear growth. ${ }^{40}$ This fact is enforced by the findings that already at birth, and throughout childhood, skeletal maturation is retarded, as is organ growth. ${ }^{41}$ These growth abnormalities include a small brain (as expressed by head circumference) ${ }^{41}$ a small heart (cardiomicria), ${ }^{42}$ and acromicria (small chin, resulting from underdevelopment of the facial bones, small hands, and small feet). ${ }^{33}{ }^{34}$ IGF-1 deficiency also causes underdevelopment and weakness of the muscular system, ${ }^{43}$ and impairs and weakens hair ${ }^{44}$ and nail growth. These findings are identical to those described in IGHD. ${ }^{45}$ IGF-1 deficiency throughout childhood causes dwarfism (final height if untreated, $100-135 \mathrm{~cm}$ in female and 110$142 \mathrm{~cm}$ in male patients), ${ }^{40}{ }^{41}$ with an abnormally high upper to lower body ratio. ${ }^{41}$ One patient reported from the UK was found to have a deletion of exons 4 and 5 of the IGF-1 gene and he too was found to have severe growth retardation. ${ }^{46}$

Impaired growth and skeletal development in the absence of IGF-1 were confirmed in mice using knockout (KO) of the IGF-1 gene or $\mathrm{GH}$ receptor gene. ${ }^{4-49}$

Knockout of the IGF-1 gene or the IGF-1 receptor gene reduces the size of mice by $40-45 \% .{ }^{49}$ Lack of the IGF-1 receptor is lethal at birth in mice owing to respiratory failure caused by impaired development of the diaphragm and intercostal muscles. ${ }^{49}$ In another model, the mice remained alive and their postnatal growth was reduced. ${ }^{50}$

In conclusion, findings in humans and in animals show that IGF-1 deficiencies causes pronounced growth retardation in the presence of increased $\mathrm{GH}$ values.

The following is a summary of the results of the growth stimulating effects of the administration of exogenous IGF-1 to children and experimental data.

\section{Growth promoting effects of IGF-1}

The first demonstration that exogenous IGF-1 stimulates growth was the administration of purified hormone to hypophysectomised rats. ${ }^{51}{ }^{52}$ After the biosynthesis of IGF-1 identical to the native hormone, ${ }^{53}$ trials of its use in

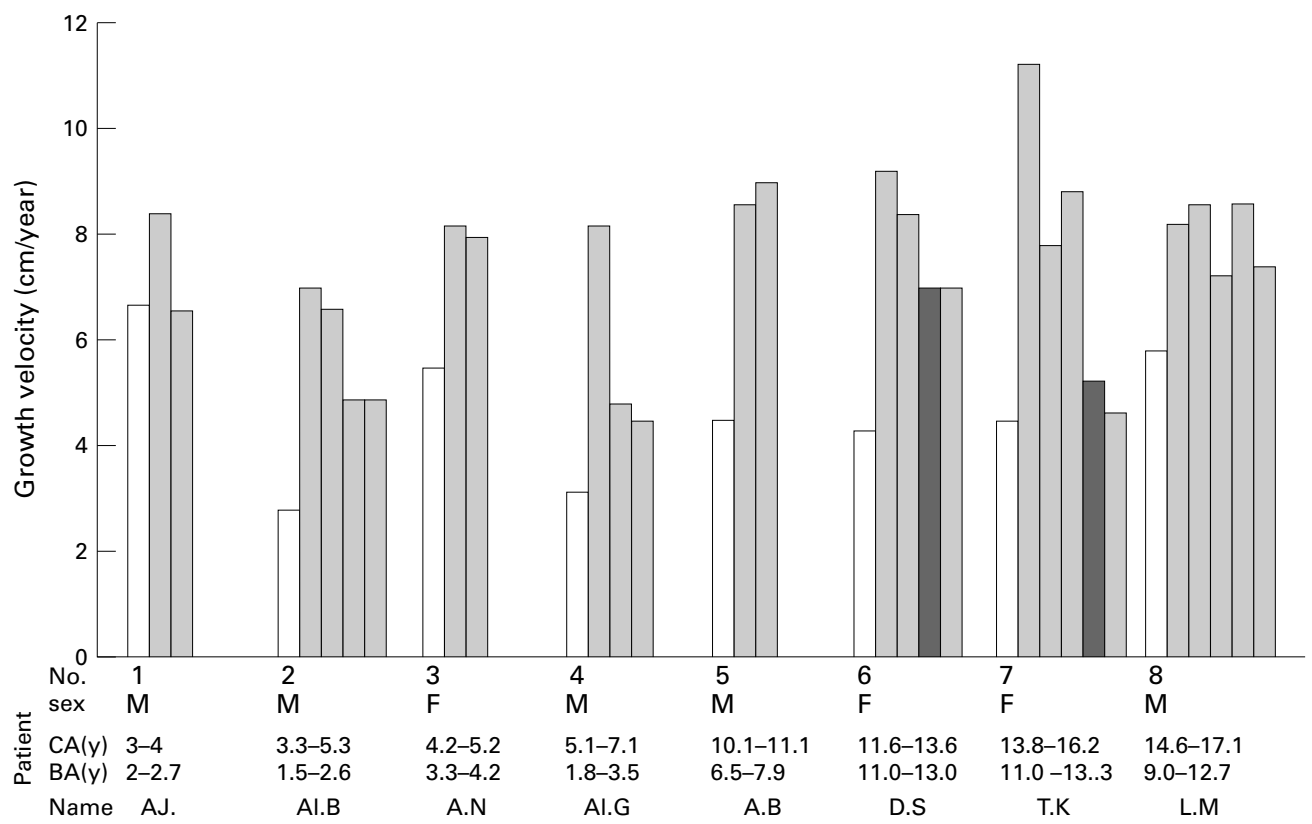

Figure 5 Growth velocity before and during insulin-like growth factor 1 (IGF-1) treatment. Note that in infancy, when the non-growth hormone/IGF-1 dependent growth velocity is relatively high (but low for age), the change induced by $I G F-1$ administration is less than in older children. 
Table 1 Linear growth response of children with Laron syndrome treated by means of insulin-like growth factor 1 (IGF-1)

\begin{tabular}{|c|c|c|c|c|c|c|c|c|c|c|c|}
\hline \multirow[b]{2}{*}{ Authors } & \multirow[b]{2}{*}{ Year } & \multirow[b]{2}{*}{ Ref. } & \multirow[b]{2}{*}{$N$} & \multicolumn{4}{|l|}{ At start } & \multicolumn{4}{|c|}{ Growth velocity (cm/year) Year of treatment } \\
\hline & & & & $\begin{array}{l}\text { Age range } \\
\text { (years) }\end{array}$ & $\begin{array}{l}B A \\
\text { (years) }\end{array}$ & $\begin{array}{l}H t S D S \\
(m)\end{array}$ & $\begin{array}{l}I G F-1 \text { dose } \\
(\mu g / k g / \text { day })\end{array}$ & 0 & $1 s t$ & $2 n d$ & $3 r d$ \\
\hline Ranke et al & 1995 & 61 & 31 & $3.7-19$ & $1.8-13.3$ & -6.5 & $40-120$ b.i.d. & $3.9(1.8)$ & $\begin{array}{l}(\mathrm{n}=26) \\
8.5(2.1) \\
(\mathrm{n}=5)\end{array}$ & $\begin{array}{l}(\mathrm{n}=18) \\
6.4(2.2) \\
(\mathrm{n}=5)\end{array}$ & $(\mathrm{n}=1)$ \\
\hline Backeljauw et al & 1996 & 62 & 5 & $2-11$ & $0.3-6.8$ & -5.6 & $80-120$ b.i.d. & 4.0 & $\begin{array}{l}9.3 \\
(\mathrm{n}=9)\end{array}$ & $\begin{array}{l}6.2 \\
(n=6)\end{array}$ & $\begin{array}{l}6.2 \\
(n=5)\end{array}$ \\
\hline Klinger and Laron & 1995 & 63 & 9 & $0.5-14$ & $0.2-11$ & -5.6 & 150-200 i.d & $4.7(1.3)$ & $\begin{array}{l}8.2(0.8) \\
(\mathrm{n}=15)\end{array}$ & $\begin{array}{l}6(1.3) \\
(\mathrm{n}=15)\end{array}$ & $\begin{array}{l}4.8(1.3)^{\star} \\
(\mathrm{n}=6)\end{array}$ \\
\hline Guevarra-Aguirre et al & 1997 & 64 & 15 & $3.1-17$ & $4.5-9.3$ & & 120 b.i.d. & $3.4(1.4)$ & $\begin{array}{l}8.8(11) \\
(\mathrm{n}=8)\end{array}$ & $\begin{array}{l}6.4(1.1) \\
(\mathrm{n}=8)\end{array}$ & $5.7(1.4)$ \\
\hline Guevarra-Aguire et al & & 64 & 8 & & & & 80 b.i.d. & $3.0(1.8)$ & $9.1(2.2)$ & $5.6(2.1)$ & \\
\hline
\end{tabular}

Growth velocity values are mean (SD).

*The younger children had a growth velocity of 5.5 and $6.5 \mathrm{~cm} /$ year.

BA, bone age; b.i.d., twice daily; CA, chronological age; i.d., once daily; Ht SDS, height standard deviation score.

humans were begun; first in adults ${ }^{54}$ and then in children. ${ }^{55} 56$ Our group was the first to introduce long term administration of biosynthetic IGF-1 to children with primary IGF-1 deficiency-primary GH insensitivity or LS. ${ }^{57}$ The finding that daily IGF-1 administration raises serum alkaline phosphatose, which is an indicator of osteoblastic activity, and serum procollagen, ${ }^{57}{ }^{58}$ in addition to IGFBP- $3,{ }^{21}$ led to long term treatment. Treatment of patients with LS was also initiated in other parts of the world. ${ }^{59-62}$ The difference between us and the other groups was that we used a once daily dose, whereas the others administered IGF-1 twice daily. ${ }^{60}$ Table 1 compares the linear growth response of children with LS treated by four different groups. It can be seen that before treatment the mean growth velocity was 3-4.7 $\mathrm{cm} /$ year and that this increased after IGF-1 treatment to $8.2-9.1 \mathrm{~cm} /$ year, followed by a lower velocity of $5.5-6.4 \mathrm{~cm} /$ year in the next two years. (In GH treatment the highest growth velocity registered is also in the first year of treatment.) Figure 5 illustrates the growth response to IGF-1 in eight children during the first years of treatment. ${ }^{65}$ Ranke and colleagues ${ }^{60}$ reported that two of their patients had reached the third centile (Tanner), as did the patient of Krzisnik and Battelino ${ }^{66}$; however, most patients did not reach a normal final height. The reasons may be late initiation of treatment, irregular IGF-1 administration, underdosage, etc. Ranke et al conclude that long term treatment of patients with LS promoted growth and, if treatment is started at an early age, there is a considerable potential for achieving height normalisation. ${ }^{60}$ Because no patient in our group was treated since early infancy to final height we cannot confirm this opinion.

When the growth response to $\mathrm{GH}$ treatment in infants with IGHD was compared with that of IGF-1 in infants with LS we found that the infants with IGHD responded faster and better than those with $\mathrm{LS}^{67}$ However, the small number of patients and the differences in growth retardation between the two groups makes it difficult to reach a conclusion.

Both hormones stimulated linear growth, but $\mathrm{GH}$ seemed more effective than IGF-1. One cause may be the greater growth deficit of the infants with LS than those with IGHD, an insufficient dose of IGF-1, or that there is a need for some $\mathrm{GH}$ to provide an adequate stem cell population of prechondrocytes to enable full expression of the growth promoting action of IGF-1, as postulated by Green and colleagues ${ }^{68}$ and Ohlson et al..$^{69}$ All the above findings based on a few clinical studies with small groups of patients and a few experimental studies remain at present controversial. The crucial question is whether there are any, and if so, whether there are sufficient IGF-1 receptors in the "progenitor cartilage zone" of the epiphyseal cartilage (fig 4) to respond to endocrine and exogenous IGF-1. Using the mandibular condyle of 2 day old ICR mice, Maor et al showed that these condyles, which resemble the epiphyseal plates of the long bones, contain IGF-1 and high affinity IGF-1 receptors also in the chondroprogenitor cell layers, which enables them to respond to IGF-1 in vitro. ${ }^{70}$

Sims et $a l,{ }^{71}$ using mice with $\mathrm{GH}$ receptor KO showed that IGF-1 administration stimulates the growth (width) of the tibial growth plate and that IGF-1 has a GH independent effect on the growth plate. These findings are similar to those found when treating hypophysectomised rats with IGF-1..$^{51}$

In conclusion, IGF-1 is an important growth hormone, mediating the anabolic and linear growth promoting effect of pituitary $\mathrm{GH}$ protein. It has a $\mathrm{GH}$ independent growth stimulating effect, which with respect to cartilage cells is possibly optimised by the synergistic action with $\mathrm{GH}$.

1 Tannenbaum GS, Ling N. The interrelationship of growth hormone $(\mathrm{GH})$-releasing factor and somatostatin in generation of the ultradian rhythm of GH secretion. Endocrinology 1984;115:1952-7.

2 Laron Z. Growth hormone secretagogues: clinical experience and therapeutic potential. Drugs 1995;50:595-601.

3 Ghigo E, Boghen M, Casanueva FF, et al., eds. Growth hor$\mathrm{G}$ igo $\mathrm{E}$, Boghen $\mathrm{M}$, Casanueva $\mathrm{FF}$, et al., eds. Growth hor-
mone secretagogues. Basic findings and clinical implications. Amsterdam: Elsevier, 1994

4 Jaffe CA, Ho PJ, Demott-Friberg R, et al. Effects of a prolonged growth hormone (GH)-releasing peptide infusion on pulsatile GH secretion in normal men. F Clin Endocrinol Metab 1993;77:1641-7.

5 Kojima M, Hosada H, Date Y, et al. Ghrelin is a growth-hormone-releasing acylated peptide from stomach. Nature 1999;402:656-60.

6 Devesa J, Lima L, Tresquerres AF. Neuroendocrine control of growth hormone secretion in humans. Trends Endocrinol Metab 1992;3:175-83.

7 Laron Z. The somatostatin-GHRH-GH-IGF-I axis. In: Merimee T, Laron Z, eds. Growth hormone, IGF-I and growth: new views of old concepts. Modern endocrinology and ( diabetes, Vol. 4. London-Tel Aviv: Freund Publishing

8 Salmon WD, Jr, Daughaday W. A hormonally controlled serum factor which stimulates sulfate incorporation by carserum factor which stimulates sulfate incorporation vitro. 7 Lab Clin Med 1957;49:825-36.

9 Froesch ER, Burgi H, Ramseier EB, et al. Antibodysuppressible and nonsuppressible insulin-like activities in 
human serum and their physiologic significance. An insulin assay with adipose tissue of increased precision and specificity. F Clin Invest 1963;42:1816-34.

10 Daughaday WH, Hall K, Raben MS, et al. Somatomedin: a proposed designation for the sulfation factor. Nature 1972; 235:107.

11 Rinderknecht E, Humbel RE. Polypeptides with nonsuppressible insulin-like and cell-growth promoting activities in human serum: isolation, chemical characterization,
and some biological properties of forms I and II. Proc Natl Acad Sci U S A 1976;73:2365-9.

12 Laron Z. Somatomedin-1 (recombinant insulin-like growth factor-I). Clinical pharmacology and potential treatment of endocrine and metabolic disorders. Biodrugs 1999;11:5570.

13 Blundell TL, Humbel RE. Hormone families: pancreatic hormones and homologous growth factors. Nature 1980 287:781-7.

14 Rinderknecht E, Humbel RE. The amino acid sequence of human insulin like growth factor I and its structural
homology, with proinsulin. F Biol Chem 1978;253:2769-76.

5 Brissenden JE, Ullrich A, Francke U. Human chromosoma mapping of genes for insulin-like growth factors I and II and epidermal growth factor. Nature 1984;310:781-4.

16 Mullis PE, Patel MS, Brickell PM, et al. Growth characteristics and response to growth hormone therapy in patients with hypochondroplasia: genetic linkage of the insulin-like growth factor I gene at chromosome $12 \mathrm{q} 23$ to the disease in a subgroup of these patients. Clin Endocrinol 1991;34: 265-74.

17 Rotwein P. Structure, evolution, expression and regulation of insulin-like growth factors I and II. Growth Factors 1991; 5:3-18

18 Hwa V, Oh Y, Rosenfeld RG. The insulin-like growth factor binding protein (IGFBP) superfamily. Endocr Rev 1999;20: 761-87

19 Lewitt MS, Saunders H, Phuyal JL, et al. Complex formation by human insulin-like growth factor-binding protein-3 and human acid-labile subunit in growt hormone-deficient rats. Endocrinology 1994;134:2402-9.

20 Laron Z, Suikkairi AM, Klinger B, et al. Growth hormone and insulin-like growth factor regulate insulin-like growth factor-binding protein-1 in Laron type dwarfism, growth hormone deficiency and constitutional short stature. Acto Endocrinol 1992;127:351-8.

21 Kanety H, Karasik A, Klinger B, et al. Long-term treatment of Laron type dwarfs with insulin-like growth factor I increases serum insulin-like growth factor-binding protein
3 in the absence of growth hormone activity. Acta Endocri3 in the absence of $g$

22 Werner H. Molecular biology of the type I IGF receptor. In: Raberts CT, Jr, eds. The IGF system molecular biology, physiology and clinical applications. Totowa, NJ: Humana Press, 1999:63-88.

23 Seino S, Seino M, Nishi S, et al. Structure of the human insulin receptor gene and characterization

24 Bondy CA Werner $\mathrm{H}$, Roberts $\mathrm{CT}$, Jr, et al. Cellular pattern of insulin-like growth factor I (IGF-I) and type I IGF of insulin-like growth factor I (IGF-I) and type I IGF receptor gene expression in early organogenesis: compari1386-98.

25 Kato H, Faria TN, Stannard B, et al. Essential role of tyrosine residues 1131,1135 , and 1136 of the insulin-like growth factor-I (IGF-I) receptor in IGF-I action. $\mathrm{Mol}$ Endocrinol 1994;8:40-50.

26 LeRoith D, Werner H, Beitner-Johnson D, et al. Molecular and cellular aspects of the insulin-like growth factor I receptor. Endocr Rev 1995;16:143-63.

27 Merimee T, Laron Z, eds. Growth hormone, IGF-I and growth: new views of old concepts. Modern endocrinology and diabetes, Vol. 4. London-Tel Aviv: Freund Publishing House Ltd, 1996.

28 D'Ercole AJ, Applewhite GT, Underwood LE. Evidence that somatomedin is synthesized by multiple tissues in the that somatomedin is synthesized
fetus. Dev Biol 1980;75:315-28

29 Nilsson A, Isgaard J, Lindhahl A, et al. Regulation by growth hormone of number of chondrocytes containing IGF-I in rat growth plate. Science 1986;233:571-4.

30 Baserga R. The IGF-I receptor in cancer research. Exp Cell Res 1999;253:1-6.

31 Rosenfeld RG, Roberts CT, Jr, eds. The IGF systemmolecular biology, physiology and clinical applications. Totowa, NY: Humana Press, 1999.

32 Zapf J, Froesch ER. Insulin-like growth factor I actions on somatic growth. In: Kostyo J, ed. Handbook of physiology,
Vol. V, Section 7. Philadelphia: American Physiological Society, 1999:663-99.

33 Laron Z, Pertzelan A, Mannheimer S. Genetic pituitary dwarfism with high serum concentration of growth hormone. A new inborn error of metabolism? Isr F Med Sci 1966;2:153-5.

34 Laron Z, Pertzelan A, Karp M. Pituitary dwarfism with high serum levels of growth hormone. Isr F Med Sci 1968;4:88394.

35 Laron Z, Pertzelan A, Karp M, et al. Administration of growth hormone to patients with familial dwarfism with high plasma immunoreactive growth hormone. Measurement of sulfation factor, metabolic and linear growth responses. F Clin Endocrinol Metab 1971;33:332-42.

36 Elders MJ, Garland JT, Daughaday WH, et al. Laron's dwarfism: studies on the nature of the defect. $f$ Pediat 1973;83:253-63.
37 Laron Z, Parks JS, eds. Lessons from Laron syndrome (LS) 1966-1992. A model of GH and IGF-I action and interacGodowski PJ, Leung DW, Meacham LR, et al. CharacterizaGodowski PJ, Leung DW, Meacham LR, et al. Characteriza-
tion of the human growth hormone receptor gene and demonstration of a partial gene deletion in 2 patients with Laron type dwarfism. Proc Natl Acad Sci U S A 1989;86:8083-7.

39 Amselem S, Duquesnoy P, Attree O, et al. Laron dwarfism and mutations of the growth hormone-receptor gene. $N$ Engl f Med 1989;321:989-95.

40 Laron Z. Laron syndrome-primary growth hormone resistance. In: Jameson JL, ed. Hormone resistance syndromes. Contemporary endocrinology, Vol. 2. Totowa, NJ: Humana Press, 1999:17-37.

41 Laron Z. Laron type dwarfism (hereditary somatomedin deficiency): a review. In: Frick P, Von Harnack GA,
Kochsiek GA, et al, eds. Advances in internal medicine and pediatrics. Berlin-Heidelberg: Springer-Verlag, 1984:11750 .

42 Feinberg MS, Scheinowitz M, Laron Z. Echocardiographic dimensions and function in adults with primary growth hormone resistance (Laron syndrome). Am f Cardiol 2000; 85:209-13.

43 Brat O, Ziv I, Klinger B, et al. Muscle force and endurance in untreated and human growth hormone or insulin-like growth factor-I-treated patients with growth hormone deficiency or Laron syndrome. Horm Res 1997;47:45-8.

44 Lurie R, Ben-Amitai D, Laron Z. Impaired hair growth and structural defects in patients with Laron syndrome (primary IGF-I deficiency) [abstract]. Horm Res 2001 [In press.]

45 Gluckman PD, Gunn AJ, Wray A, et al. Congenital idiopathic growth hormone deficiency associated with prenatal and early postnatal growth failure. $f$ Pediatr 1992;121:920-3.

46 Woods KA, Camacho-Hubner C, Savage MO, et al. Intrauterine growth retardation and postnatal growth failure associated with deletion of the insulin-like growth factor I gene. N Engl f Med 1996;335:1363-7.

47 Zhou Y, Xu BC, Maheshwari HG, et al. A mammalian model for Laron syndrome produced by targeted disruption of the mouse growth hormone receptor/binding protein gene (the La

48 Sjogren K, Bohlooly YM, Olsson B, et al. Disproportional skeletal growth and markedly decreased bone mineral content in growth hormone receptor -/- mice. Biochem Biophys Res Commun 2000;267:603-8.

49 Accili D, Nakae J, Kim JJ, et al. Targeted gene mutations define the roles of insulin and IGF-I receptors in mouse embryonic development. F Pediatr Endocrinol Metab 1999; 12:475-85.

50 Holzenberger M, Leneuve P, Hamard G, et al. A targeted partial invalidation of the insulin-like growth factor-I receptor gene in mice causes a postnatal growth deficit. Endocrinology 2000;141:2557-66.

51 Schoenle E, Zapf J, Humbel RE, et al. Insulin-like growth factor I stimulates growth in hypophysectomized rats. Nature 1982;296:252-3.

52 Guler H-P, Zapf J, Scheiwiller E, et al. Recombinant human insulin-like growth factor I stimulates growth and has distinct effects on organ size in hypophysectomized rats. Proc Natl Acad Sci U S A 1988;85:4889-93.

53 Niwa M, Sato Y, Saito Y, et al. Chemical synthesis, cloning and expression of genes for human somatomedin C (insulin like growth factor I) and 59Val somatomedin C. Ann N Y Acad Sci 1986;469:31-52.

54 Guler HP, Zapf J, Froesch ER. Short term metabolic effects of recombinant human insulin like growth factor in healthy of recombinant human insulin like grow

55 Laron Z, Klinger B, Silbergeld A, et al. Intravenous administration of recombinant IGF-I lowers serum GHRH and TSH. Acta Endocrinol 1990;123:378-82.

56 Klinger B, Garty M, Silbergeld A, et al. Elimination characteristics of intravenously administered rIGF-I in Laro type dwarfs (LTD). Dev Pharmacol Ther 1990;15:196-9.

57 Laron Z, Klinger B, Jensen LT, et al. Biochemical and hormonal changes induced by one week of administration of rIGF-I to patients with Laron type dwarfism. Clin Endocrinol 1991;35:145-50.

58 Klinger B, Jensen LT, Silbergeld A, et al. Insulin-like growth factor-I raises serum procollagen levels in children and adults with Laron syndrome. Clin Endocrinol 1996;45:4239 .

59 Underwood LE, Backeljauw P. IGFs: function and clinical importance of therapy with recombinant human insulinlike growth factor I in children with insensitivity to growth hormone and in catabolic conditions. I Intern Med 1993;234:571-7.

60 Ranke MB, Savage MO, Chatelain PG, et al. Long-term treatment of growth hormone insensitivity syndrome with IGF-I. Horm Res 1999;51:128-34.

61 Ranke MB, Savage MO, Chatelain PG, et al. Insulin-like growth factor (IGF-I) improves height in growth hormone insensitivity: two years results. Horm Res 1995;44:253-64.

62 Backeljauw PF, Underwood LE, The GHIS Collaborative Group. Prolonged treatment with recombinant insulin-like growth factor I in children with growth hormone insensitivity syndrome-a clinical research center study. $\mathcal{F}$ Clin Endocrinol Metab 1996;81:3312-17.

63 Klinger B, Laron Z. Three year IGF-I treatment of children with Laron syndrome. $\mathcal{F}$ Pediatr Endocrinol Metab 1995;8: 149-58. 
64 Guevara-Aguirre J, Rosenbloom AL, Vasconez O, et al. Two year treatment of growth hormone $(\mathrm{GH})$ receptor deficiency
with recombinant insulin-like growth factor-I in 22 children: comparison of two dosage levels and to GH treated GH deficomparison of two dosage levels and to GH treated

65 Laron Z, Lilos P, Klinger B Growth curves for Laron syndrome. Arch Dis Child 1993;68:768-70.

66 Krzisnik C, Battelino T. Five year treatment with IGF-I of patient with Laron syndrome in Slovenia (a follow-up report). F Pediatr Endocrinol Metab 1997;10:443-7.

67 Laron Z, Klinger B. Comparison of the growth-promoting effects of insulin-like growth factor I and growth hormone in the early years of life. Acta Paediatr 2000;89:38-41.
68 Green H, Morikawa M, Nixon T. A dual effector theory of growth hormone action. Differentiation 1985;29:195-8.

69 Ohlson C, Bengtsson BA, Isaksson OG, et al. Growth hormone and bone. Endocr Rev 1998;19:55-79.

70 Maor G, Laron Z, Eshet R, et al. The early postnatal development of the murine mandibular condyle is regulated by endogenous insulin-like growth factor-I. F Endocrinol 1993; 137:21-6.

71 Sims NA, Clement-Lacroix P, Da Ponte F, et al. Bone homeostatis in growth hormone receptor-null mice is restored by IGF-I but independent of Stat5. 7 Clin Invest 2001;106:1095-103.

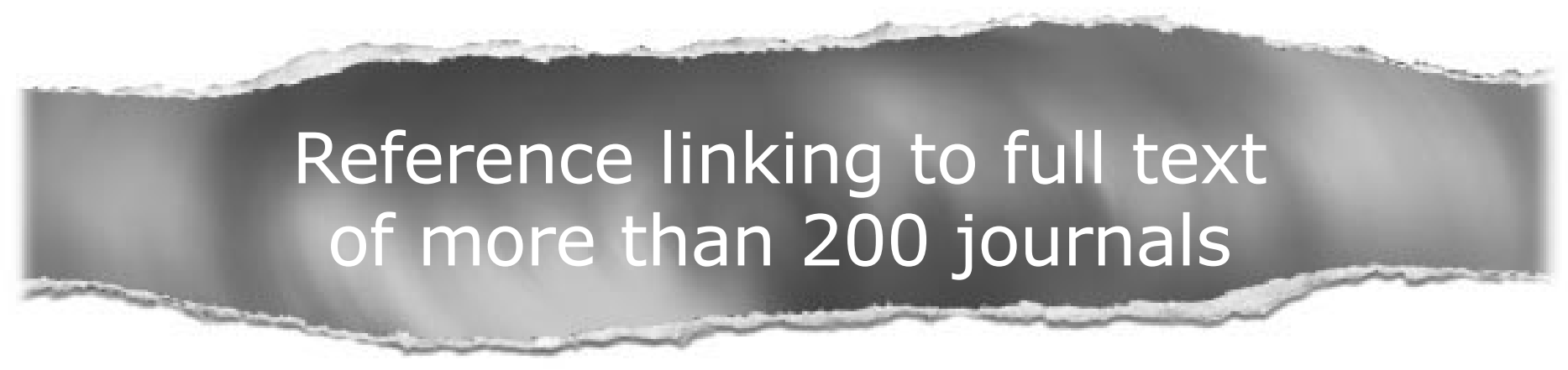

Toll free links

You can access the FULL TEXT of articles cited in the Journal of Clinical Pathology online if the citation is to one of the more than 200 journals hosted by HighWire (http://highwire.stanford.edu) without a subscription to that journal. There are also direct links from references to the Medline abstract for other titles.

www.jclinpath.com 